\title{
Challenges in ICT Integration among Malaysian Public Primary Education Teachers: The Roles of Leaders and Stakeholders
}

\author{
https://doi.org/10.3991/ijet.v14i24.12101 \\ Nor Asiah Razak, Habibah Ab Jalil( ${ }^{(凶)}$, Ismi Arif Ismail \\ Universiti Putra Malaysia, Selangor, Malaysia \\ habibahjalil@upm.edu.my
}

\begin{abstract}
The major role of ICT tools is a means to communicate and collaborate in a globalized, technological world in the knowledge society. In education, the role of ICT is paramount, especially for supporting teachers in ICT integrated teaching. However, little research has been conducted particularly in Asia-Pacific, on the interaction between teachers and ICT integration influenced by their school's stakeholder, which lead to successful implementation among teachers in teaching. Therefore, the purpose of this study is to investigate the challenges faced by teachers to ICT tools and how the schools' leaders and schools' stakeholders overcome these challenges. By employing a qualitative research methodology, data were collected using a multi-method of data collection, including in-depth interviews, non-participants observations, field notes, and document analysis. The findings uncovered three themes for existing challenges and overcoming challenges. Three themes for the challenges are the inadequate schools' ICT tools, failure to commit to the schools' regulations, and failure to comply with the schools' regulations. The three themes for overcome challenges are assisted performance, sharing ideas, and distributed leadership style. This study can be an exemplar for other schools in strategizing ICT integration for teachers in teaching.
\end{abstract}

Keywords - ICT tools, ICT integration, schools' leaders, schools' stakeholders, primary education

\section{Introduction}

In recent years, an increasing amount of literature emphasizes the roles of ICT as a tool to support 21st-century skills, motivation, knowledge sharing, and assessment purposes. The 21 st-century skills consist of critical thinking, problem-solving, creativity, written and oral communication, leadership, adaptability, collaboration, selfdirection, responsibility, and global awareness [1]. These skills can enhance students learning either in collaborative or personalized learning, helping them to compete at the global marketplace [2], [3]. In the same vein, Voogt, Knezek, Cox, Knezek, and Brummelhuis [4] in their article "under which conditions does ICT have a positive effect on teaching and learning? A call to action", claimed that ICT are multiple tech- 
nology-enhanced pedagogies in the curriculum's attempts to address the issues of students' needs in 21st-century skills. Instead of ICT merely helping students to develop 21st-century skills, a qualitative phenomenology study in USA found ICT also can help students boost their motivation and widen their knowledge and information and support the assessment of 21 st-century skills [5].

ICT is most likely crucial as millennial students are digital learners who are highly devised, highly networked, highly interactive, and highly social [6]. Educators have to "speak in students' language," then they will learn better, and at the same time, the use of emerging technologies can be cost-effective. This happens as the world has introduced Web 2.0 technology, putting the power to learn, collaborate, create, and share resources in the hands of the students with free access tools, such as https://www.draw.io/ and https://www.mockupworld.co/all-mockups/ an online diagram software to draw flowchart, chart and any diagram. According to Ertmer et al. [7], Web 2.0 refers to "second-generation Internet applications that do something unique, practical, and/or powerful while enabling social connections, and thus, greater collaboration among users" (p. 424-425). This view is supported by Mohammad and Kulkarni [9] who asserted that the emerging technologies, such as Web 2.0 have opened up cost-effective approaches, providing the reach of education to the youth as well as to those who need continuing education for meeting the demands of a fast-changing society.

The major role of ICT is as means to communicate and collaborate in a globalized, technological world in the knowledge society. In education, the role of ICT is paramount especially, for supporting teachers in teaching. Based on the literature, scholars use various definitions to describe ICT in education. For example, in developed countries such as Canada, ICT is defined as "technological tools used to manipulate and communicate information, such as recording media (e.g., CDs/DVDs), broadcasting systems (e.g., radio, television), computing hardware and software (e.g., World Wide Web, Web 2.0, email), and mobile networks devices (e.g., cell phones, smartphones)" [10]. Another study in primary education in Cyprus revealed that ICT are used by teachers for updating and enriching lessons through the Web or technical and administrative facilities by providing storage for retrieving and sharing of information, preparing and presenting efficiency [11]. In developing country such as Malaysia, ICT refers "to the common technology-based tools that are using in schools such as computer, Laptop, LCD, digital photocopy machine, Digital Audio and Video devices, digital camera, scanner, DVD player and multimedia projector" [12]. Throughout the present study, the researcher adapted these scholars' definitions because of the ICT's definitions between developed and developing countries quite similar. However, the definition of ICT should align with international level. Most of these definitions, a definition from Aucoin [10] fixes the environment of the millennium era. For the purposes of this study, ICT is defined as the communication tools and web-based system especially the Web 2.0 to support teachers in teaching process for acquiring, sharing, and creating knowledge. 


\subsection{Problem statement}

There are increasing numbers of studies on the positive impact of ICT assisted teaching and learning on the learning outcome of students, lead to successful ICT integration in schools [13]. We also have seen the emergence of technologies, lead to an engaging learning environment [14]. However, little research has been conducted particularly in Asia-Pacific on the interaction between teachers and ICT integration that shaped by their social environment, namely school's stakeholder, lead to successful ICT integration among teachers in teaching. The stakeholder in education refers to "a person who has a vested interest in the success or failure of a school or education system including administrators, teachers, staff members, students, parents, families, community members, local business leaders, and elected" [15]. Based on the available literature in Malaysian context, a report by the Malaysia's MOE claimed that approximately $80 \%$ of teachers spent less than one hour a week integrating ICT in teaching. Similarly, United Nations Educational, Scientific and Cultural Organization (UNESCO) reports revealed that teachers' ICT integration in Malaysian schools has not gone much further than the use of word-processing application as an instructional tool in teaching [16]-[18]. They claim that the above situations have occurred as there is little support from the school's leaders, especially for resources and ICT training [18]. School's leaders, especially the headmasters, one of the most significant catalysts in the successful ICT integration among teachers [19], [20]. Therefore, the purpose of this study is to investigate the challenges faced by teachers to ICT tools and how the schools' leaders and schools' stakeholders overcome these challenges.

In 2017, thirteen out of 212 primary schools from the federal territory of peninsular Malaysia were awarded with 5-star. Malaysia's ETD has endorsed a list of schools with different levels of ICT integration, ranging from 1-star (lowest) to 5-star (highest) to portray the implementation level of ICT integration in each school based on the SSQS [21]. As only few primary schools received the 5-star recognition, it is imperative to explore why that certain schools are more prominent than others for ICT integration in teaching. The findings could offer an answer to the minimal teachers' ICT integration in teaching. For the study purposes, the following research questions are addressed:

- What are the challenges that teachers faced to use ICT tools in their teaching?

- How the school's leaders and school's stakeholder overcome these challenges?

\subsection{Effective ICT integration in teaching}

Although teachers do integrate ICT, it does not guarantee that they understand effective ICT integration. There are two components in the process of effective ICT integration proposed by Nishant Gunjan [22] and Lin, Wang, and Lin [24], they are the ICT integration approach; and the level of ICT integration. ICT integration can be viewed based on three approaches in teaching: from ICT, about ICT, and with ICT [22]. Teaching from ICT refers to the use of ICT to convey specific information or skills through the application of technologies such as web-based-assisted instruction and web-based tutoring systems. Teaching about ICT refers to the use of technology 
that reflects traditional teaching environments including the teaching of the technology itself such as students learn the computer literacy topic to understand how a computer works in keyboarding skills; ethical uses of computers; and a particular programming language. Teaching with ICT refers to the current thinking about the use of ICT to support teaching for achieving meaningful learning. Lin, Wang, and Lin [24] proposed a pedagogical 'technology model for teachers' ICT integration in public high schools in China. The two-dimensional level model consists of 'technology' and 'pedagogy' dimensions as a guide for teachers' progressions in terms of ICT integration. There are four levels in the pedagogy dimension: direct teaching; cognitively active learning; constructive learning; and social learning. These levels are defined based on four factors: teacher pedagogical beliefs; instructional strategies used; teacher-student interactions; and the types of tasks students are expected to carry out. Subsequently, the technology dimension contains eight levels, ranging from Level 0 (nonuse) to Level 7 (implementing sophisticated instructional applications). The eight levels are defined based on three factors: whether a teacher is a passive consumer or an active producer of the ICT-based resources; the level of sophistication of the ICT tools that a teacher uses; and as well as the richness of functionality of an ICT-based product developed by a teacher. These qualitative case studies revealed that this model is able to be adapted by teachers in guiding them in ensuring effective and progressive ICT integration.

ICT integration can mediate teachers to effective teaching which their leads to meaningful learning through the use of emerging technologies in the knowledge society environments. In addressing the issues of pedagogical aspects, modern technology offers tools with various functionality, such as content management system and Web 2.0. For example, Google Hangout and ZohoWriter can be used for collaboration and sharing knowledge that is crucial in the teaching and learning process [25]. Nevertheless, to attain effective ICT integration in teaching, a mix-method study for secondary teachers in Norway revealed that teachers must give time to find their way to integrate ICT in their teaching method [26]. Students can access the information at any time and everywhere before they come to class as preparation for learning or doing homework. This view is supported by García-Valcarcel [24] who conducted a quantitative study involving teachers in primary, secondary, and upper secondary schools in Spain and found the effectiveness of teaching mediated by technology tools in the teaching process will bring meaningful learning and experiences for students.

Teachers' competency in ICT integration is needed and must align with the students' needs for effective ICT integration [28]. On the other hand, if teachers could not have the right skills to integrate ICT into their teaching, it shall lead to ineffective ICT integration. Case studies conducted in Korea to understand teachers' ICT capacity for the 21st-century learning environment found the new roles of teachers in ICT integration include new media literacy skills and adaptive expertise with efficiency and innovation [29]. This view promotes the idea that teachers should have a range of different skills including technical and communication skills. It could be obtained through learning from Scratch for computational and creative thinking and learning robotics as emerging technology for convergent and divergent thinking. Teachers must also have technical skills and knowledge in dealing with educational videos, 
stimulation, storage of data, the use of databases, mind-mapping, guided discovery, brainstorming, music, and World Wide Web [28].

Given all that has been mentioned so far in this section, the effectiveness of ICT integration in teaching depends on the approaches. Teaching with ICT is the best approach to achieve meaningful learning [30]. The other two approaches of ICT integration in teaching; about ICT and from ICT can be applied at the initial process of teaching to introduce ICT tools to students, and then teachers able to integrate ICT. For teachers to integrate ICT, they need to understand the roles of ICT integration as part of a teacher's teaching process which can lead to meaningful learning. Furthermore, a sophisticated understanding of ICT integration in teaching is required to ascertain the impact of ICT integration on effective teaching which leads to meaningful learning. Teachers' resistance to ICT integration is the most likely reason that hindered them from achieving the high level of ICT integration in teaching.

\section{$2 \quad$ Literature Review}

\subsection{Sociocultural perspectives on the challenges in ICT integration among teachers}

For more than a decade, the literature shows that the majority of studies related in the West and Asia revealed various factors that could contribute to the challenges in ICT integration among teachers. If the challenges ICT integration are not overcome, the problem that occurred in a school can hinder the teachers' ICT integration in their teaching. The hindrance can either be extrinsic to teachers (first-order barrier) or intrinsic to teachers (second-order barrier) [31]. This study's stance is that sociocultural factors are extrinsic or external to teachers in integrating ICT in their teaching. From sociocultural perspectives, Vygotsky's [31], [32] emphasizes the interrelated between an individual and its social environment to mediates an action. Thus, the stance in a sociocultural perspective is appropriate in studying the interaction between teachers and ICT integration. Based on the reviewed literature and the focus of this study, the sociocultural factors only discussed into two themes:

- School's leadership towards ICT Integration among teachers

- Support from the school's stakeholder

School's leadership towards ICT integration among teachers: The role of school leadership is challenging in supporting and implementing ICT integration in schools. School's leadership refers to the role of headmasters in the schools [20]. Previous studies indicated that teachers perceive headmasters' leadership as one of the most significant catalysts influencing ICT integration among teachers [19], [20]. A quantitative study in Flemish primary school in Belgium indicated that headmasters are the catalyst and facilitator of ICT integration in teaching [19]. Moreover, a qualitative study in Quebec English Schools urges that school's leaders clearly work towards the vision and mission for technology integration and plan for ICT integration comprehensively. The school leaders must also drive the investment of ICT resources for 
teaching purpose [20]. This view on school's leadership is also written by Bannayan et al. [33] as one of the UNESCO reports about ICT in primary education.

In order to successfully integrate ICT in teaching, school leaders should employ certain leadership style in schools. Therefore, leadership styles have been extensively studied such as charismatic leader in [34] and distributed leadership approach in [35] . Previous studies in Singapore suggested that a school leader must employ a distributed leadership approach to ensure success in any activity especially ICT integration activities related to teachers [35]. The distributed leadership refers to the aspect that assists the headmaster to handle the demands by sharing the responsibilities with middle managers such as instructional programs and ICT coordinator while embarking on ICT integration [36]. Instead of distributed leadership, a good leader must use a charismatic style in leading his/her professional team in Israeli schools [34]. Tubin [34] also found that charismatic style brings led to positive communication regarding ICT between superior and subordinate while at the same time supporting staff as they grapple with the emerging technologies.

Support from the school's stakeholder: A considerable amount of the literature has been published pertaining support from the school's stakeholder towards teachers' ICT integration in teaching that leads to successful ICT integration in schools [20], [37]-[39]. One study in Turkey adopted a sociocultural approach and found that the teachers perceived the administration as significant factors that hinder their willingness to introduce technology into teaching [39]. Other studies also claimed that sufficient support from administrators and ICT coordinators would increase the educators' commitment to integrating ICT. For example, Goktas et al. [40] argued that ongoing support given to teachers would give them confidence for ICT integration. Goktas et al. [40] also claimed that the support of the ICT coordinator and the school administrator is necessary to assure the effectiveness of ICT integration process. In line with Rabah [20], perceived school headmaster's leadership is one of the most convincing catalysts in influencing the success of ICT integration. She further claimed that supportive school leadership and clear ICT vision from the leaders at the school as well as investments in ICT integration such as ICT training are worth the efforts.

The currently available literature shows that technical support challenges in every school are to cater to the technical issues on ICT integration. For example, previous studies found that insufficient technical support specialists to fix the technical problem, lead to the challenge of teachers' ICT integration [20], [40], [41]. Lim [42] contended that teachers could successfully organize their students in a classroom from engaging in deviant behaviors that might disrupt the lesson will only be possible with the support given by the technical assistant. Rabah [20] suggested that the school's leaders should manifest a precise vision of technical support which clearly states in the school's vision for preparing technical personnel to ease ICT integration implementation. In case of technical problem, the technical support team has to ascertain that any technology failures before, during and after ICT integration in teaching get fix [35].

Previous studies emphasized the challenges of peer support in ICT integration among teachers. Zah et al. [43] claimed that administrative work would burden or distract the teachers to focus on teaching. In fact, some scholars suggested that the 
teachers' workloads such as clerical work need to be reduced [40]. One of the efforts to reduce teachers' workload, as suggested by scholars, is to provide peer support through the collaboration and sharing knowledge influenced teachers' ICT integration [39], [40]. For example, a study in Singapore suggests that in addressing teachers' workload, teachers must conduct sharing sessions to design and develop ICT-based lessons [44]. Similar result was found in a study on secondary schools in Iran in that sharing of information and cooperation among teachers were also the major factors influencing teachers' motivation to integrate ICT in their lessons [37].

\section{$3 \quad$ Methodology}

\subsection{Research design}

A qualitative multiple-case study was adopted to understand the interaction between teachers and ICT integration in two Malaysian public primary schools. Based on Mayring [46], the cross-cases analysis was utilizing a qualitative content analysis to navigate the case study data.

Participants: This study adopted a method of purposive sampling with criterionbased case selection to select the schools and participants. Based on Creswell [47] and Patton [48] , the primary selection criterion of the sampled was as follows:

- Having achieved the highest level

- Being awarded a five-star ranking in integrating ICT based on Malaysia's SSQS in 2017

To select the participants, the researchers divided the selection into two categories:

- Primary participants

- Secondary participants

The primary participants were teachers who are the main implementers of ICTintegrated teaching and therefore can claim a significant stake in the success of the process. The secondary participants consisted of the headmaster, ICT coordinator, head of units, and ICT teacher because these participants were the communities that could influence or hinder ICT-integrated teaching. The researchers have interviewed fourteen participants. The selection of subjects taught by participants is varied to ensure the implementation of ICT integration in schools is the across-curriculum. The point of data saturation determined the number of participants. The study reached saturation when no new themes emerged from the analysis of data collections [49], [50]. Demographic information about the participants is provided in Table 1. For confidentiality purposes, the participants' original names have been substituted with the pseudonym. Based on the mentioned criteria above, two public primary schools were selected in this study: School P and School K. 
Table 1. Demographic information of the participants

\begin{tabular}{|l|l|l|l|}
\hline \multicolumn{1}{|c|}{ Schools } & \multicolumn{1}{c|}{ Participants' pseudonym } & \multicolumn{1}{c|}{ Position } & \multicolumn{1}{c|}{ Qualification } \\
\hline School P & Mr. Siew & Headmaster & Degree \\
\hline $\mathrm{P}$ & Mrs. Liew & ICT coordinator & Degree \\
\hline $\mathrm{P}$ & Mr. Shin & Head of unit (Mathematics) & Degree \\
\hline $\mathrm{P}$ & Miss Ng & ICT teacher & Degree \\
\hline $\mathrm{P}$ & Mrs. Hidayah & English teacher & Diploma \\
\hline $\mathrm{P}$ & Mr. Loh & Mathematics teacher & Degree \\
\hline $\mathrm{P}$ & Miss Siti & Bahasa Malaysia teacher & Degree \\
\hline School K & Mrs. Habsah & Headmaster & Master \\
\hline $\mathrm{K}$ & Mr. Halim & ICT coordinator & Degree \\
\hline $\mathrm{K}$ & Mrs. Hanan & Head of unit (Science) & Degree \\
\hline $\mathrm{K}$ & Mr. Abu & ICT teacher & Diploma \\
\hline $\mathrm{K}$ & Mrs. Asmah & Science teacher & Degree \\
\hline $\mathrm{K}$ & Miss Ani & Bahasa Malaysia teacher & Degree \\
\hline $\mathrm{K}$ & Mr. Hassan & Mathematics teacher & Degree \\
\hline
\end{tabular}

Methods of data collection: To address the two research questions, the researcher used the multi-method data collection. A primary method of data collection included three sessions of an in-depth interview. Another method that was also used as a triangulation was the non-participant observations, and document analysis known as the multi-method approach of data to ensure the data is valid and reliable [51], [52]. Table 2 summarizes these data collection methods and procedure. Fig. 1 shows a brief of the process of data collection in one school at a time. The aim was to collect data from one school to another to make it easier due to familiarity and making it possibly faster [51].

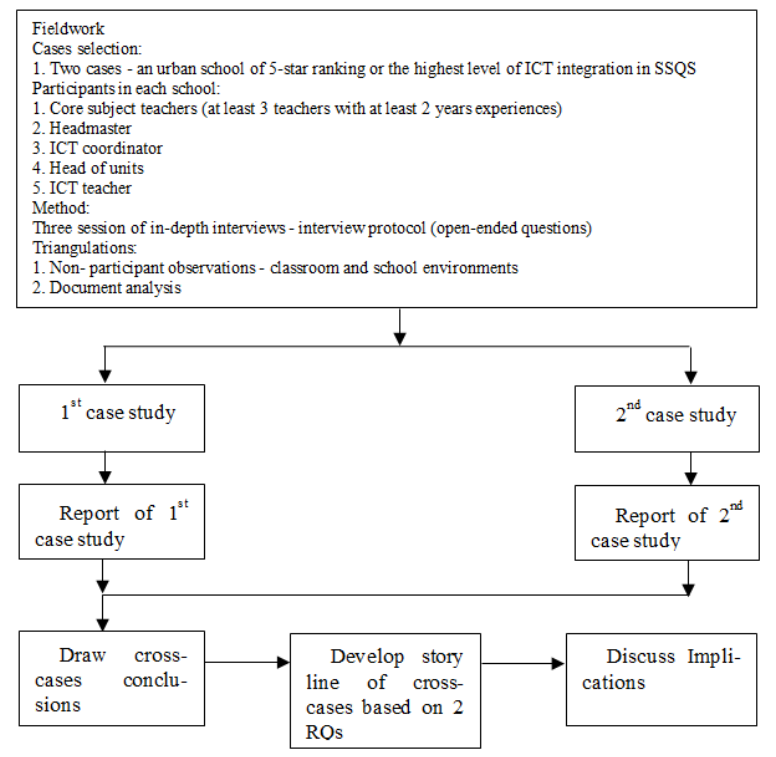

Fig. 1. Representation of data collection process in the study 
Table 2. Data collection procedure summary

\begin{tabular}{|c|c|c|}
\hline Methods & Information Sources & \begin{tabular}{|c|} 
Procedure \\
\end{tabular} \\
\hline In-depth interviews & $\begin{array}{l}\text { Primary participants Secondary partic- } \\
\text { ipants }\end{array}$ & $\begin{array}{l}\text { Face to face interviews with open-ended } \\
\text { interview questions were used for probing, } \\
\text { the interviews were audiotaped using a Sony } \\
\text { digital voice recorder, then transcribed each } \\
\text { interview verbatim immediately after each } \\
\text { interview session. }\end{array}$ \\
\hline & & Took note and took picture. \\
\hline $\begin{array}{l}\text { Non- participant } \\
\text { observations }\end{array}$ & $\begin{array}{l}\text { Observed students' activities in the } \\
\text { classrooms and computer labs, ICT } \\
\text { facilities in the classrooms, computer } \\
\text { labs, and access center including } \\
\text { Internet connection, availability of } \\
\text { software and courseware applications. }\end{array}$ & $\begin{array}{l}\text { The researcher took the picture during the } \\
\text { observation as the participants did not allow } \\
\text { the class to be videotaped. The classroom } \\
\text { observation was carried out before and after } \\
\text { the interview sessions for one particular } \\
\text { subject in a class. The observation involved } \\
\text { the researcher sitting at the back of the class } \\
\text { during the ICT-integrated teaching. }\end{array}$ \\
\hline \multirow{3}{*}{ Document Analysis } & $\begin{array}{l}\text { Reviewed documents on the Malay- } \\
\text { sia's MOE official website, schools' } \\
\text { official website, schools' shared video } \\
\text { on YouTube. }\end{array}$ & \multirow{3}{*}{$\begin{array}{l}\text { Read and reread all sources and took note } \\
\text { any information related to the purpose of the } \\
\text { study. }\end{array}$} \\
\hline & $\begin{array}{l}\text { Reviewed documents related to rules } \\
\text { and regulations that governed ICT } \\
\text { integration in the schools such as } \\
\text { school handbooks (school vision and } \\
\text { mission), ICT strategic plans, ICT } \\
\text { policies. }\end{array}$ & \\
\hline & $\begin{array}{l}\text { Reviewed the participants' shared } \\
\text { documents and pictures, and pictures } \\
\text { that the researcher took during the } \\
\text { observation. }\end{array}$ & \\
\hline
\end{tabular}

Method of data analysis: The inductive category formation process was used to answer the two research questions. As shown in Fig. 2, the researcher follows eight steps of inductive category formation process. The researcher notes the idea in a memo icon in a hermeneutic unit of ATLAS.ti or margin note on the paper to the data attributed to the codes if the researcher has any idea for coding at that time. The researcher continues the same process for the rest of the transcripts and compares the segments of the data for each research question and coded them. Sometimes, the researcher comes across a piece of data which is relevant but not related to the research questions of the study; in these cases, the researcher labelled them with question marks them as "related?" to later decide about them and the process of data analysis. 


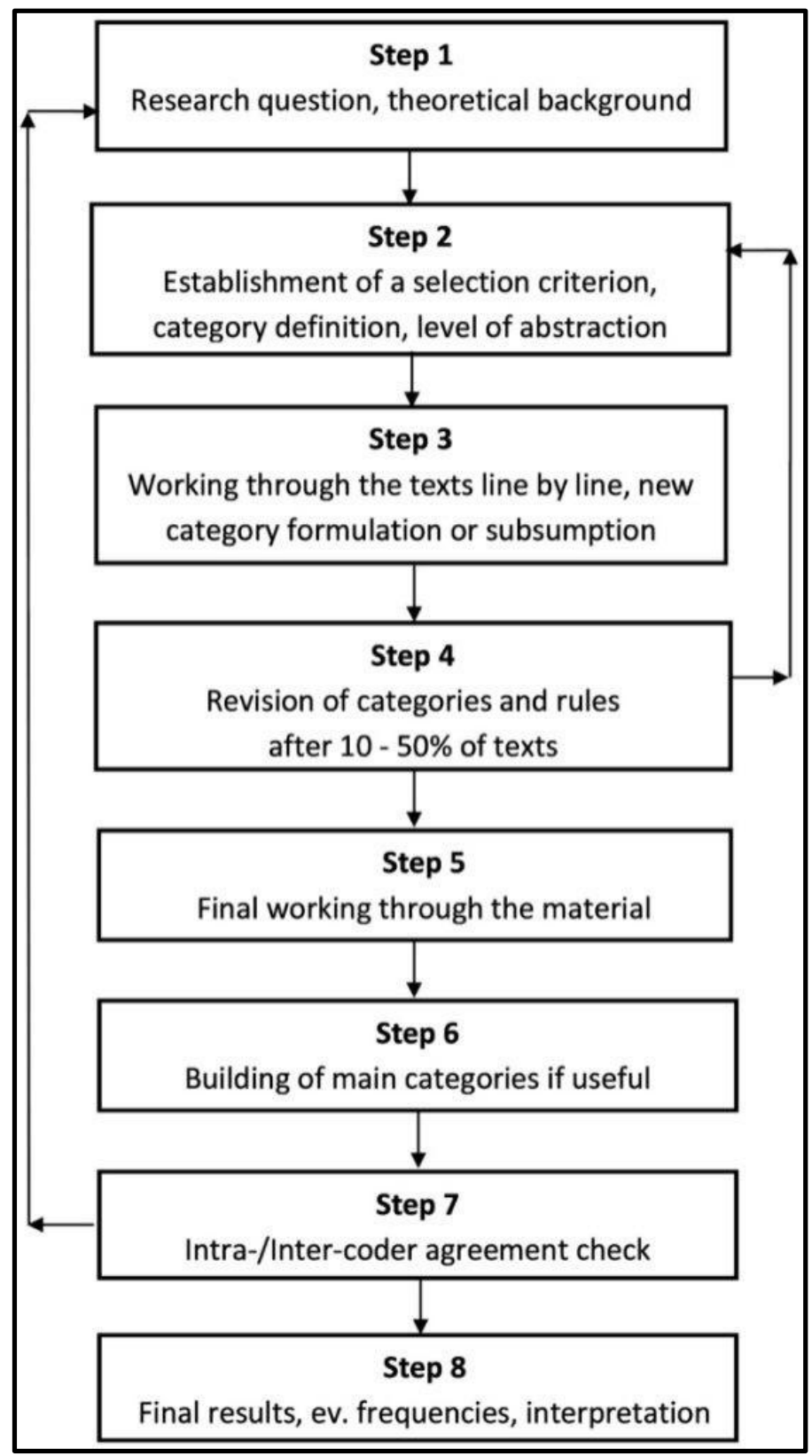

Fig. 2. The process of inductive category formation [46] 


\section{$4 \quad$ Findings and Discussions}

The findings are present on how the schools' leaders and schools' stakeholders in overcoming the challenges for achieving 5 stars ranking or successful ICT integration implementation in the schools. Table 3 demonstrates the two research questions that addressed in this study, methods of data collection used to generate the themes based of data collected.

Table 3. Challenges and overcoming the challenges in ICT integration among teachers

\begin{tabular}{|c|c|c|c|}
\hline No. & $\begin{array}{l}\text { Research } \\
\text { Question }\end{array}$ & $\begin{array}{c}\text { Data collected for themes of challenges and overcoming the chal- } \\
\text { lenges in ICT integration among teachers }\end{array}$ & Methods \\
\hline \multirow{3}{*}{1} & \multirow{3}{*}{\begin{tabular}{|l|} 
\\
\\
\\
\\
What are the \\
challenges that \\
teachers faced \\
to use ICT \\
tools in their \\
teaching? \\
\\
\\
\\
\\
\\
\\
\end{tabular}} & $\begin{array}{l}\text { Inadequate Schools' ICT Tools: } \\
\text { School P- “unfortunately, the equipment's life cycle only lasts five } \\
\text { years and should be maintained or replaced. We don't have a budget } \\
\text { for that. Is ok if just repair because he has a technician. But we can't } \\
\text { afford to buy the new one because the government didn't provide the } \\
\text { budget for purchasing ICT. Plus, we only have one technician, he } \\
\text { couldn't repair all the equipment in short period." (Miss Ng) } \\
\text { School K- "Last time, I couldn't book the computer lab for students } \\
\text { one a week the computer lab full. That time we only have one com- } \\
\text { puter lab, not access center and open area. So, it not catered our needs } \\
\text { to bring students one a week." (Mr. Hassan) }\end{array}$ & $\begin{array}{l}\text { Interviews with } \\
\text { all the partici- } \\
\text { pants, observa- } \\
\text { tions, and doc- } \\
\text { ument analysis }\end{array}$ \\
\hline & & $\begin{array}{l}\text { Failure to commit to the schools' regulations: } \\
\text { School P-"we felt pressured when the information that we were } \\
\text { supposed to receive didn't reach us because the ICT teachers were } \\
\text { busy. Our head of unit also busy, but not sure other head of units } \\
\text { because I told you based on my experience in my department." (Mrs. } \\
\text { Hidayah) } \\
\text { School K-"Sometimes teachers claimed that the ICT teachers did not } \\
\text { do their work. I mean the teachers did not get the information they } \\
\text { supposed to get it. Sometimes the teachers told me that they received } \\
\text { information late. Actually, I discussed this issue in a meeting, but the } \\
\text { ICT teachers claimed that they were burdened with another task } \\
\text { would make them late in delivering information and others activities." } \\
\text { (Mrs. Hanan) }\end{array}$ & $\begin{array}{l}\text { Interviews with } \\
\text { the head of unit, } \\
\text { ICT coordina- } \\
\text { tors, and teach- } \\
\text { ers }\end{array}$ \\
\hline & & $\begin{array}{l}\text { Failure to comply with the schools' regulations: } \\
\text { School P1-“we received a poor response when we asked teachers to } \\
\text { attend the ICT workshops even stating that it is compulsory. They } \\
\text { would usually say they were busy at work, have prior engagements } \\
\text { and would skip the training. If they did not attend the workshops, they } \\
\text { usually lost information because we trained on how to use our book- } \\
\text { ing system, installed school Management system, and did training on } \\
\text { other courseware and applications. That is the challenge that we faced } \\
\text { as administrators." (Mrs. Siew) } \\
\text { School K1- "Most of the issue related to the difficulties of all parties } \\
\text { to comply the school's regulations. They always saying difficult to } \\
\text { use ICT into teaching, but, they do not try to use it. (Mrs. Habsah) }\end{array}$ & $\begin{array}{l}\text { Interviews with } \\
\text { the headmasters }\end{array}$ \\
\hline 2 & $\begin{array}{l}\text { How the } \\
\text { school's } \\
\text { leaders and } \\
\text { school's } \\
\text { stakeholder } \\
\text { overcome } \\
\text { these chal- }\end{array}$ & $\begin{array}{l}\text { Assisted performance: } \\
\text { The roles of schools' stakeholders in School P: PTA: Donate money } \\
\text { through the 'Charity Night'. The alumni and parents who are experts } \\
\text { in certain areas: provide valuable guidance and advice to schools in } \\
\text { various fields such as banking, accounting, financial, sports, technol- } \\
\text { ogy, and landscape. The school board helps the schools to generate } \\
\text { income by installing the solar panel at the school, and sell to TNB }\end{array}$ & $\begin{array}{l}\text { Interviews with } \\
\text { all the partici- } \\
\text { pants, observa- } \\
\text { tions, and doc- } \\
\text { ument analysis }\end{array}$ \\
\hline
\end{tabular}




\begin{tabular}{|l|l|l|}
\hline lenges? & $\begin{array}{l}\text { (energy company). The income was used to buy equipment such as } \\
\text { schools installed WIFI for better Internet connection and to top-up the } \\
\text { government's budget for equipment maintained or replaced. } \\
\text { The roles of schools' stakeholders in School K: PTA: Collect dona- } \\
\text { tion from the crowd. Crowd-funding campaign to purchase technolo- } \\
\text { gies. Technology developers transferred technologies to upgrade the } \\
\text { computer labs. Technology developers also contribute their technolo- } \\
\text { gies because the school like a showroom to their technology as this } \\
\text { school is a role model for technology in education. }\end{array}$ & \\
\hline $\begin{array}{l}\text { Sharing ideas } \\
\text { School P- "We also seek help from the PTA, the school board, and } \\
\text { alumni. Besides fund, they have members who are experts in various } \\
\text { fields who can provide valuable guidance and advice". (Mr. Siew) } \\
\text { School K: The technology developers coming to the schools to share } \\
\text { their experiences about their product with teachers and students. }\end{array}$ & $\begin{array}{l}\text { Interviews with } \\
\text { the headmasters, } \\
\text { observations, } \\
\text { and document } \\
\text { analysis }\end{array}$ \\
\hline $\begin{array}{l}\text { Distributed leadership style: } \\
\text { School P-“our headmaster is very supportive, he always attends our } \\
\text { ICT workshops. For me, I am excited to attend the workshop when I } \\
\text { see the enthusiasm of our headmaster for implementing ICT in our } \\
\text { school." (Miss Siti) } \\
\text { School K: Miss Ani explained that "they were becoming increasingly } \\
\text { frustrated at the lack of support and recognition that they were receiv- } \\
\text { ing from the administrators. However, it is changed when we see our } \\
\text { headmaster's concern for us." (Miss Ani) }\end{array}$ & $\begin{array}{l}\text { Interviews with } \\
\text { all the partici- } \\
\text { ants, observa- } \\
\text { tions, and doc- } \\
\text { ument analysis }\end{array}$ \\
\hline
\end{tabular}

\subsection{Challenges that teachers faced in using ICT tools in their teaching}

The first research question identified the challenges that teachers faced to use ICT tools in their teaching could hinder teachers' ICT integration in schools. Three themes emerged pertaining to the challenges to answer the first research question of both School P and K. The three themes are: 1. inadequate schools' ICT tools; 2. failure to commit to the schools' regulations; and 3. failure to comply with the schools' regulations.

Inadequate schools' ICT tools: The findings revealed that the teachers from both Schools P and K faced challenges between attaining to integrate ICT into teaching with the inadequate schools' ICT tools. This finding was consistent to Goktas et al. [40] who claimed that the primary schools in Turkey lacked hardware and appropriate high-quality teaching software materials due to limited financial provision for ICT tools. Goktas et al. [40] study was quite convincing because they made a comparison study between the year 2005 and 2011. Based on the participants perspectives, despite the breadth of provided hardware, it was not able to meet the objective of the teacher to conduct ICT-integrated teaching. The ICT tools did not sufficiently cater to the number of students in the classroom. Moreover, the broadband did not provide enough Internet access for all of the teachers and students. For example, Miss $\mathrm{Ng}$, the ICT teacher from School P, mentioned that "unfortunately, the equipment's life cycle only lasts five years and should be maintained or replaced." Mr. Hassan, a mathematics teacher in School K, shared the pictures of the poor Internet connection and insufficient ICT tools in ICT-integrated teaching activities during his Mathematics lessons as illustrated in Fig. 3. However, he believed that ICT has the potential to enhance 
students' learning by, among others, enhancing students' focus in the classFig. 3 showed his classroom environment.

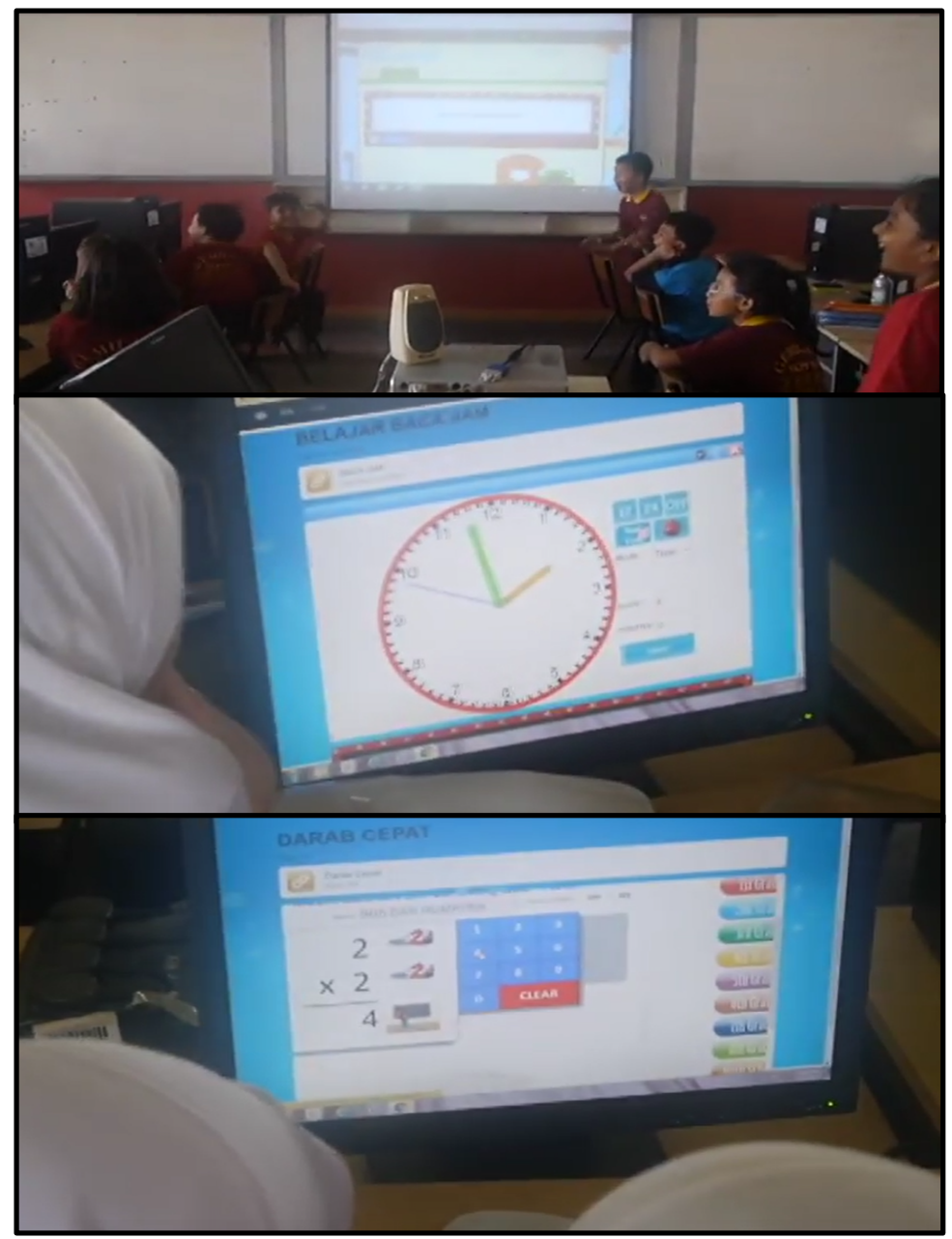

Fig. 3. Classroom environment of school K

Failure to commit to the schools' regulations: The findings revealed that both School $\mathrm{P}$ and $\mathrm{K}$ shared similar pressures because the schools demand more work commitments that are not related to teaching from the subordinates. Therefore, teachers, ICT teachers, and head of units felt pressured as they cannot commit to the schools' regulations. This view was supported by the head of unit said:

Sometimes teachers claimed that the ICT teachers did not do their work. I mean the teachers did not get the information they supposed to get it. Sometimes the teachers told me that they received information late. Actually, I discussed this issue in a meet- 
ing, but the ICT teachers claimed that they were burdened with another task would make them late in delivering information and others activities. (Mrs. Hanan)

An English teacher explained that:

We felt pressured when the information that we were supposed to receive didn't reach us because the ICT teachers were busy. Our head of unit was also busy, but not sure other head of units because I told you based on my experience in my department. (Mrs. Hidayah)

This finding is in agreement with previous works that had looked into high-income and middle-income economies on time management, which emerged as a key factor with a considerable influence on the school's stakeholder failure to commit to the schools' regulation [41], [44].

Failure to comply with the schools' regulations: The findings revealed that the challenges faced by both Schools P and K that several schools' stakeholders are failed to comply with and were unresponsive towards regulations imposed by the schools. As evidence for this theme, the researcher presented the excerpt from headmaster of School $\mathrm{P}$ when the researcher asked the question about his challenge as a top management to manage the school. He said that:

We received a poor response when we asked teachers to attend the ICT workshops even when we insisted that it was compulsory. They would usually say they were busy at work, have prior engagements and would skip the training. If they did not attend the workshops, they usually lose information because we trained them how to use our booking system, installed the school's management system, and did training for other courseware and applications. (Mr. Siew)

The headmistress of school K explained that "Most of the issue were related to the difficulties of all parties to comply with the school's regulations. They always said it was difficult to integrate ICT in teaching, but, they have not tried to integrate it." This finding was supported by Ali et al. [41], who proposed that teachers are reluctant to comply with the schools' regulations because they have insufficient time to master ICT skills. Thus, the teachers resisted change to implement a new teaching method. Teachers resistance to change is not a new issue in Malaysia as it exists for more than a decade and would exist whenever a new technology introduced.

\subsection{How the school's leaders and school's stakeholder overcome these challenges?}

For the second research question: How the school's leaders and school's stakeholder overcome these challenges of influencing teachers' ICT integration in teaching? Three themes emerged for overcoming the challenges that occurred in both School P and K. The themes were:

1. Assisted performance

2. Sharing of ideas

3. Distributed leadership.

Assisted performance: The findings from both School P and $\mathrm{K}$ had revealed that the assisted performance is crucial to determine the success of the teachers' ICT inte- 
gration in schools. According to the findings of this study, assisted performance is defined as a personnel's initiative to assist the schools, in particular, the teachers for students benefits. The personnel support is not only from experts, administrative team, technical team, and peers who are IT-savvy. The support could be from non-experts, as long as they are willing to help schools in anyway such as donation, providing manpower and equipment. The involvement of the school's community is one part of the assisted performance. The school's stakeholder could include the PTA, alumni, technology developers, local business owner, and the school board. However, this study did not support the findings of prior studies concerning assisted performance involved in helping successful ICT integration in schools. According to Tharp and Gallimore [53], assisted performance is defined as "what a novice can do with help, with the support of the environment, or others, and of the self," (p. 30). They derived the concept of assisted performance from Vygotsky which includes two key components of Vygotsky's primary vehicle for effective instruction. The "zone of proximal development" (ZPD): a performance by the novice and assistance by the expert, and the more capable peer. On other hands, ICT-integrated teaching can occur when assistance is offered, or performance requires assistance in various forms including financial provision. In this sense, expert guidance amplifies novice performance but does so by drawing on novice contributions. Likewise, this study expands the definition of assisted performance beyond the relationships of expert and novice.

Sharing ideas: The interview revealed that all the teachers and other participants agreed that sharing ideas with other schools' stakeholders, including the PTA, school board, alumni, and technology developers was a valuable tool for them to improve their skills, especially skills involved in teaching and learning. In fact, some of the participants, such as the headmasters and ICT coordinators who initially influenced teachers to integrate ICT, predicted that this was one of the most important experiences that any schools could provide for their teachers. For example, the headmaster of School P explained that:

We also seek help from the PTA, the school board, and alumni. Besides fund, they have members who are experts in various fields who can provide valuable guidance and advice. (Mr. Siew)

The researcher found similar results in School $\mathrm{P}$ when the researcher conducted document analysis, observation and interviews in School K. The ICT teacher, Mr. Abu shared the pictures that showed the technology developers coming to the schools to share their experiences about their product with teachers and students as shown in Fig. 4. 


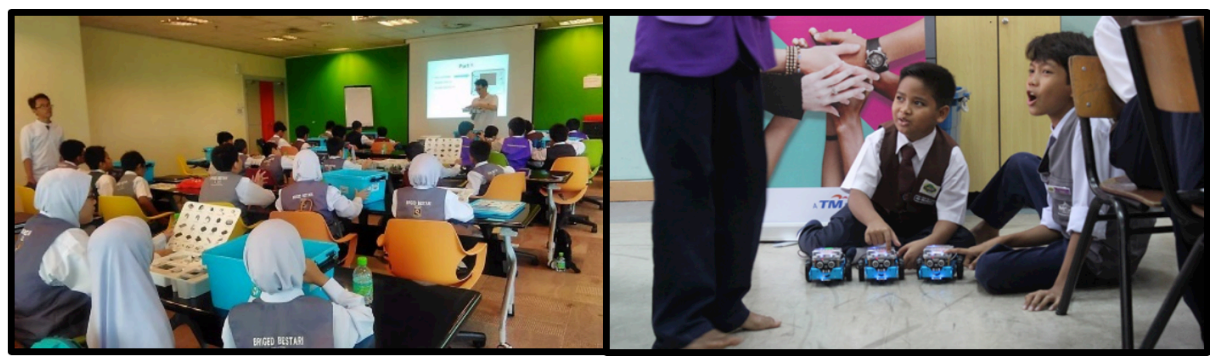

Fig. 4. The technology developers giving opportunity to students and teachers to experience their products

As time goes by, the issue of school's stakeholder could not commit to the schools' regulations as they do not have enough time, would decrease as the sharing of ideas takes place. This finding supported by Goktas et al. [40] and Demiraslan and Usluel [39] proposed the significant of peer support, emphasizing the collaboration and sharing of knowledge had led to successful teachers' ICT integration. Another previous study claimed that in order to reduce teachers' workload, the scholars suggested that the sharing of ideas is a must. For example, a study in Singapore suggested that in addressing teachers' workload, teachers must do sharing sessions to design and develop ICT-based lessons [44]. Recent studies in secondary schools in Iran concurred with this study's finding that the sharing of information and cooperation among teachers is one of the major factors that influenced teachers' motivation to integrate ICT in their lessons [37].

Distributed leadership: Distributive characteristics refer to a quality of leadership that the headmasters have in transferring the duties to their subordinates for managing any activities including ICT training. In School P, the headmaster himself monitored all the management procedures to ICT tools, especially for teaching purposes. He monitored the ICT in-house training assisted by the ICT coordinator and ICT teachers. Miss Siti, a Malay Language teacher mentioned that "our headmaster is very supportive, he always attends our ICT workshops. For me, I am excited to attend the workshop when I see the enthusiasm of our headmaster for implementing ICT in our school." In this sense, the headmaster leads by setting the direction (i.e., mission) for the school - to nurture and inspire learners to work to the best of their potential through innovative approaches in an engaging environment, leveraging on technologies and research. In the area of distributed leadership, the headmaster was arguably the 'leader of leaders' - the headmaster was one of the subjects who propagated the integration of ICT into the curriculum and had continuously became a strong proponent of ICT usage in education. School K also provides frequent ICT training. They conduct their training at the school which involves the district teachers because most of the teachers who are IT savvy are the national ICT coaches. Miss Ani shared a picture (Fig. 5) that she kept to illustrate one of the ICT trainings that her school had hosted. She also explained that "they were becoming increasingly frustrated at the lack of support and recognition that they were receiving from the administrators. However, it is changed when we see our headmaster's concern for us." 


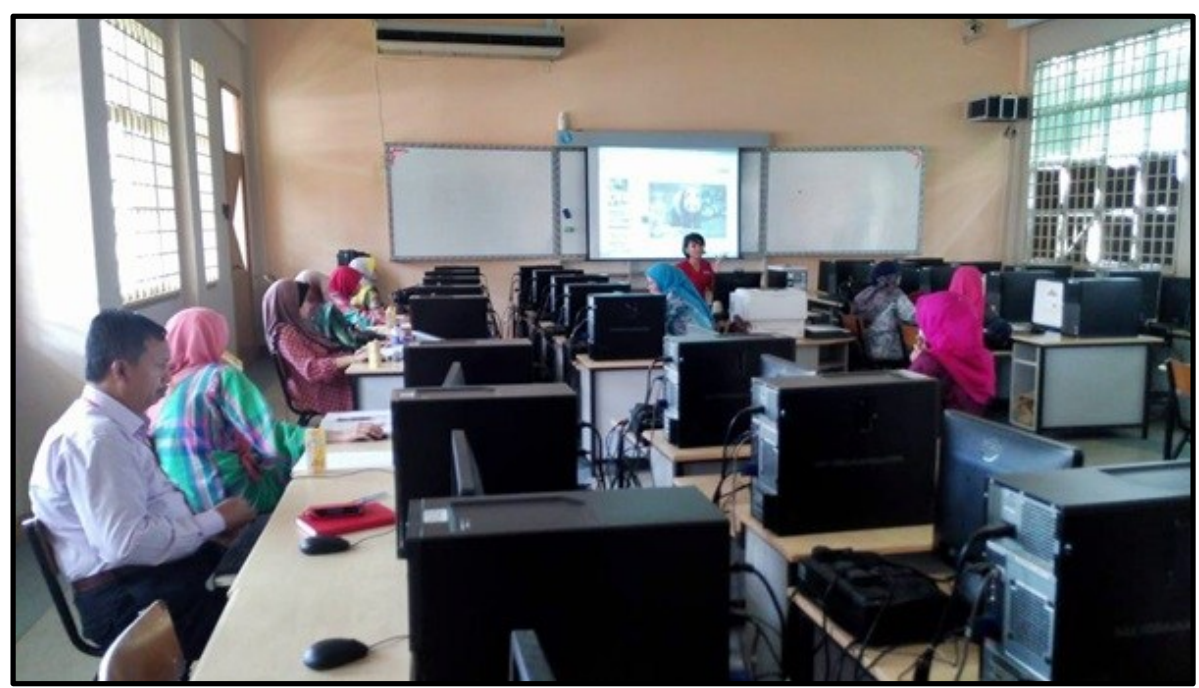

Fig. 5. School K hosted ICT trainings across districts

This finding is supported by Heller and Fireston [54] who proposed that the leadership can be distributed in various ways to work in a collaborative mode at times and in parallel at others for achieving a maximum outcome. In task to bring the schools to a higher level can be undertaken by multiple leaders including the headmasters, ICT coordinators, and any teachers who are responsible as leaders [55]. This finding was consistent with Tay and Lim [56] who proposed that the success of ICT integration in schools not only depends on the headmaster but the involvement all the leaders who participated in the schools' activities. In this sense, this theme was validated by the notion "distributed leadership" presented by Senge et al. [36] which defined distributed leadership as assisting the headmaster in handling the demands by sharing responsibilities with middle managers such as instructional programs and ICT coordinator while embarking on ICT integration. The definition of distributed leadership that influenced teachers' ICT integration as derived from this study has a remarkable similarity with the definition of distributed leadership mentioned in [33]. This study also supported prior studies that argued that distributed leadership is one of the most significant catalysts that affected the successful integration of ICT [19], [20].

\section{Conclusion}

Six themes include three challenges, and three overcome the challenges that influenced the teachers' ICT integration, which led to successful ICT integration in the schools. The findings showed that the schools' leaders and schools' stakeholders were helped the teachers to eliminate these challenges. Sometimes, not all the challenges can be eliminated, well-intended interventions from the schools' leaders and schools' stakeholders can decrease that burdened the teachers faced. Schools' leaders, especially the headmasters, should play their role in strategizing teachers' ICT integration in 
teaching by managing and transferring the ICT integration vision and mission to their subordinates. The schools' leaders should emphasize the use of Web 2.0 to their teachers as this ICT tool would give an impact on cost saving for teaching purposes. This study hoped can give implications as an exemplar for other schools that share similar characteristics and contexts, in strategizing ICT integration for teachers in teaching.

\section{Acknowledgement}

We would like to acknowledge the founder 'Innohub, Putera Science Park, Universiti Putra Malaysia, Selangor, Malaysia' in providing a grant for our research title 'Market Validation for Establishing Future Classroom System'. The grant number is 9003226. This article is a part of the research.

\section{$7 \quad$ References}

[1] D. Cogan-Drew, "21st century skills," eLearn, vol. 2010, no. 2, p. 6, 2010.

[2] W. F. Keane and T. Keane, "Deep learning, ICT and 21st century skills deep learning, ICT and 21 st century skills," Australian Catholic University. p. 14, 2014.

[3] M. Frydenberg and D. Andone, "Learning for 21st century skills," in International Conference on Information Society (i-Society), 2011, pp. 314-318.

[4] J. Voogt, G. Knezek, M. Cox, D. Knezek, and A. ten Brummelhuis, "Under which conditions does ICT have a positive effect on teaching and learning? A call to action," J. Comput. Assist. Learn., vol. 29, no. 1, pp. 4-14, 2013. https://doi.org/10.1111/j.1365-2729.20 11.00453.x

[5] A. J. Hussain, S. Morgan, and D. Al-Jumeily, "How does ICT affect teachings and learning within school education," in 4th International Conference on Developments in eSystems Engineering, 2011, pp. 250-254. https://doi.org/10.1109/dese.2011.50

[6] Y. T. C. Yang, "Virtual CEOs: A blended approach to digital gaming for enhancing higher order thinking and academic achievement among vocational high school students," Comput. Educ., vol. 81, pp. 281-295, 2014. https://doi.org/10.1016/j.compedu.2014.10.004

[7] P. A. Ertmer, A. T. Ottenbreit-Leftwich, O. Sadik, E. Sendurur, and P. Sendurur, "Teacher beliefs and technology integration practices: A critical relationship," Comput. Educ., vol. 59, no. 2, pp. 423-435, 2012. https://doi.org/10.1016/j.compedu.2012.02.001

[8] João Eurico et al., "Portuguese guide lines for the use of biological agents in rheumatoid arthritis - october 2011 update," Acta Reumatol. Port., vol. 36, no. 4, pp. 385-388, 2011.

[9] Mohammad Amiri IRAN and Kulkarni V.V, "Facilitation Skills: Developing Facilitative Leadership,” Rev. Res., 2015.

[10] R. Aucoin, "Information and communication technologies in international education: A Canadian policy analysis," Int. J. Educ. Policy Leadersh., vol. 6, no. 4, pp. 1-11, 2011.

[11] T. Maria Mama and S. Hennessy, "Developing a typology of teacher beliefs and practices concerning classroom use of ICT," Comput. Educ., vol. 68, pp. 380-387, 2013. https://doi. org/10.1016/i.compedu.2013.05.022

[12] S. Ghavifekr, T. Kunjappan, L. Ramasamy, and A. Anthony, "Teaching and learning with ICT tools: Issues and challenges from teachers' perceptions," Malaysian Online J. Educ. Technol., vol. 4, no. 2, pp. 38-57, 2016. 
[13] A. A. Radzak and N. M. Noh, "Kepuasan Pengajaran dan Pembelajaran Bahasa Melayu di SJK (C) Melalui Penggunaan Papan Putih Interaktif," in Educational Technology Division, 1st Ed., K. A. A. Salam, A. A. Bakar, and M. A. bin Aripin, Eds. Malaysia: Educational Technology Division, 2017, p. 100.

[14] B. H. M. Keling, A. R. Madar, and K. A. A. Salam, "Penggunaan Virtual Learning Environment (VLE) oleh Guru-Guru di Sekolah Rendah," in Educational Technology Division, vol. 136, 2013, pp. 91-107.

[15] Great Schools Partnership, "Stakeholders," The Glossary of Education Reform, 2014. [Online]. Available: https://www.edglossary.org/stakeholder/\%0D. [Accessed: 11-Oct2019].

[16] Ministry of Education Malaysia [MOE], "Malaysia Education Blueprint 2013 - 2025," 2013.

[17] Ministry of Education Malaysia [MOE], “Annual Report 2017: Malaysian Education Blueprint 2013-2025,” Putrajaya, Malaysia, 2018.

[18] Educational Technology Division of Malaysia [ETD], "Dokumentasi Kajian \& Laporan Pemantauan 2013-2015," Kuala Lumpur, Malaysia, 2017.

[19] J. Tondeur, H. van Keer, J. van Braak, and M. Valcke, "ICT integration in the classroom: Challenging the potential of a school policy," Comput. Educ., vol. 51, no. 1, pp. 212-223, 2008. https://doi.org/10.1016/j.compedu.2007.05.003

[20] J. Rabah, "Benefits and challenges of information and communication technologies ( ICT ) integration in Québec english schools," Turkish Online J. Educ. Technol., vol. 14, no. 2, pp. 24-31, 2015.

[21] Multimedia Super Corridor [MSC], "Smart School Qualification Standards (SSQS), 2009.

[22] Nishant Gunjan, "Enhancing teaching and learning through technology integration in education," Int. J. Humanit. Soc. Sci., vol. 5, no. 1, pp. 165-172, 2016.

[23] J. M. C. Lin, P. Y. Wang, and I. C. Lin, "Pedagogy technology: A two-dimensional model for teachers' ICT integration,” Br. J. Educ. Technol., vol. 43, no. 1, pp. 97-108, 2012. https://doi.org/10.1111/j.1467-8535.2010.01159.x

[24] K. Yang, T.-H. Wang, and Y.-C. Kao, "How an interactive whiteboard impacts a traditional classroom,” Educ. as Chang., vol. 16, no. 2, pp. 313-332, 2012. https://doi.org/10.1080/ $\underline{16823206.2012 .745759}$

[25] F. Hamidi, M. Meshkat, M. Rezaee, and M. Jafari, "Information technology in education," Procedia Comput. Sci., vol. 3, pp. 369-373, 2011. https://doi.org/10.1016/j.procs.2010.12. $\underline{062}$

[26] G. Wikan and T. Molster, "Norwegian secondary school teachers and ICT," Eur. J. Teach. Educ., vol. 34, no. 2, pp. 209-218, 2011.

[27] A. García-Valcarcel, "Integrating ICT into the teaching-learning process: Colloquium," Br. J. Educ. Technol., vol. 41, no. 5, 2010.

[28] M. Drent and M. Meelissen, "Which factors obstruct or stimulate teacher educators to use ICT innovatively?,” Comput. Educ., vol. 51, no. 1, pp. 187-199, 2008. https://doi.org/10. 1016/j.compedu.2007.05.001

[29] H. Kim, H. Choi, J. Han, and H. J. So, "Enhancing teachers' ICT capacity for the 21st century learning environment: Three cases of teacher education in Korea," Australas. J. Educ. Technol., vol. 28, no. 6, pp. 965-982, 2012. https://doi.org/10.14742/ajet.805

[30] L. Y. Tay, S. K. Lim, C. P. Lim, and J. H. L. Koh, "Pedagogical approaches for ICT integration into primary school English and mathematics: A Singapore case study," Australas. J. Educ. Technol., vol. 28, no. 4, pp. 740-754, 2012. https://doi.org/10.14742/ajet.838 
[31] P. A. Ertmer, "Addressing first-and second-order barriers to change: Strategies for technology integration,” Educ. Technol. Res. Dev., vol. 47, no. 4, pp. 47-61, 1999. https://doi. org/10.1007/bf02299597

[32] L. S. Vygotsky, Mind in Society: The Development of Higher Psychological Processes. US: Harvard University Press, 1997.

[33] H. E. Bannayan et al., ICT in primary education, vol. 1. United Nations Educational, Scientific and Cultural Organization [UNESCO], 2012.

[34] D. Tubin, "When ICT meets schools: Differentiation, complexity and adaptability," J. Educ. Adm., vol. 45, no. 1, pp. 8-32, 2007. https://doi.org/10.1108/09578230710722430

[35] S. Divaharan and C. P. Lim, "Secondary school socio-cultural context influencing ICT integration: A case study approach," Australas. J. Educ. Technol., vol. 26, no. 6, pp. 741763, 2010. https://doi.org/10.14742/ajet.1040

[36] P. M. Senge, N. H. Cambron-McCabe, T. Lucas, B. Smith, J. Dutton, and A. Kleiner, Schools that Learn. 2000.

[37] S. L. Mirzajani, H., Mahmud, R., Fauzi Mohd Ayub, A., \& Wong, "Teachers' acceptance of ICT and its integration in the classroom," Qual. Assur. Educ., vol. 24, no. 1, pp. 26-40, 2016. https://doi.org/10.1108/qae-06-2014-0025

[38] G. Sang, M. Valcke, J. van Braak, J. Tondeur, and C. Zhu, "Predicting ICT integration into classroom teaching in Chinese primary schools: Exploring the complex interplay of teacher-related variables," J. Comput. Assist. Learn., vol. 27, no. 2, pp. 160-172, 2011. https:// doi.org/10.1111/j.1365-2729.2010.00383.x

[39] Y. Demiraslan and Y. K. Usluel, "ICT integration processes in Turkish schools: Using activity theory to study issues and contradictions," Australas. J. Educ. Technol., vol. 24, no. 4, pp. 458-474, 2008. https://doi.org/10.14742/ajet.1204

[40] Y. Goktas, N. Gedik, and O. Baydas, "Enablers and barriers to the use of ICT in primary schools in Turkey: A comparative study of 2005-2011," Comput. Educ., vol. 68, pp. 211222, 2013. https://doi.org/10.1016/j.compedu.2013.05.002

[41] W. Z. W. Ali, H. M. Nor, A. Hamzah, and H. Alwi, "The conditions and level of ICT integration in Malaysian mart schools," Int. J. Educ. Dev. Using Inf. Commun. Technol., vol. 5, no. 2, pp. 21-31, 2009.

[42] C. P. Lim, "Effective integration of ICT in Singapore schools: Pedagogical and policy implications," Educ. Technol. Res. Dev., vol. 55, no. 1, pp. 83-116, 2007. https://doi.org/10. 1007/s11423-006-9025-2

[43] W. Zah, W. Ali, and H. M. Nor, "The implementation of ICT integration in Malaysian smart schools," Education, 2010.

[44] C. P. Lim and C. S. Chai, "An activity-theoretical approach to research of ICT integration in Singapore schools: Orienting activities and learner autonomy," Comput. Educ., vol. 43, no. 3, pp. 215-236, 2004. https://doi.org/10.1016/j.compedu.2003.10.005

[45] P. Mayring, "Qualitative content analysis," Forum Qual. Soc. Res., vol. 1, no. 2, 2000.

[46] P. Mayring, Qualitative Content Analysis: Theoretical Foundation, Basic Procedures and Software Solution. Klagenfurt, Austria, 2014.

[47] J. W. Creswell, Qualitative Inquiry \& Research Design: Choosing among Five Approaches. Thousand Oaks, California: Sage Publications, Inc, 2007.

[48] M. Q. Patton, "Qualitative Designs and Data Collection," in Qualitative Research and Evaluation Methods, 4rd ed., Thousand Oaks, California: Sage Publications, Inc, 2015, pp. 244-326.

[49] Y. S. Lincoln and E. G. Guba, Naturalistic Inquiry. Beverly Hills: CA: Sage, 1985.

[50] S. B. Merriam and E. J. Tisdell, Qualitative Research: A Guide to Design and Implementation. US: John Wiley \& Sons, Inc., 2016. 
[51] B. Gillham, Case Study Research Methods. London: Continuum, 2000.

[52] R. K. Yin, Case Study Research: Design and ethods, 3rd ed., vol. 26, no. 1. London, UK: SAGE Publications Inc, 2013.

[53] R. Tharp and R. Gallimore, "Rousing minds to life: Teaching, learning and schooling in social context," J. Des. Res., vol. 5, no. 2, pp. 155-171, 1988. https://doi.org/10.1017/cbo 9781139173698.001

[54] M. F. Heller and W. A. Firestone, "Who's in charge here? Sources of leadership for change in eight schools," Elem. Sch. J., vol. 96, no. 1, pp. 65-86, 1995. https://doi.org/10. $\underline{1086 / 461815}$

[55] A. Lieberman and L. Miller, "Teachers as leaders," Educ. Forum, vol. 69, no. 2, pp. 151162,2005

[56] L. Y. Tay and C. P. Lim, “An Activity Theoretical Approach towards Distributed Leadership for One-to-One Computing in a Singapore Elementary School," in Activity Theory in Education, Eds., D. S. P. Gedera and P. J. Williams, Eds. Netherlands: Sage Publications, Inc, 2016, pp. 87-106. https://doi.org/10.1007/978-94-6300-387-2_6

\section{Authors}

Nor Asiah Mohamad is a researcher in the field of educational technology at the Faculty of Educational Studies, Universiti Putra Malaysia (UPM). Her research focuses on information and communication technology (ICT) in education with a specialization in 21st-century teaching environments. The combination of her educational background in software engineering, business administration, and marketing, plus a strong passion for research in technology in education, has led her to involve in UPM's commercialization hub known as InnoHub. She participated in the InnoHub program as the CEO of one of the University's Spin-off Companies, namely EduBits Sdn. Bhd. This company is one of the start-ups that carryout the innovation to commercialization that belongs to the Faculty of Educational Studies.

Habibah Ab Jalil is an academic at the Faculty of Educational Studies, Universiti Putra Malaysia (UPM) since 2000. She is an instructor for courses related to information and communication technology (ICT) in education for graduate and undergraduate students. In 2016, she was assigned as the lead researcher for a national study on MOOC which has significant impact on UPM and the country at large. She was involved in the development of various national policies including the National policy on e-Learning (DePAN) and DePAN 2.0, Malaysian MOOC Development Guideline, National Open Educational Resources and National Gamification. At the university level, she was a Coordinator and Associate Fellow of Teaching and Learning Innovation Division, Centre for Academic Development (CADe), UPM, in which she particularly coordinated programs and research related to SCL, Blended Learning, LMS, MOOC and OER. She is also the Technology Coordinator of Putra Future Classroom (PFC), Faculty of Educational Studies, undertaking the role in its establishment and strategizing the operation and direction of the first PFC in UPM.

Ismi Arif Ismail is the Deputy Dean for Research and Graduate Studies at the Faculty of Educational Studies, Universiti Putra Malaysia. He was the former Deputy Director at the National Higher Education Leadership Academy, responsible for the teaching and learning leadership training of university lecturers. He was also a former 
member of the National MOOC Technical Committee facilitating and overseeing the implementation of MOOC in Malaysian Universities. Together with his team, Dr. Ismi currently is working on a project called Putra Future Classroom which championed the need to redesign the curriculum, learning space and technology in classrooms at universities and schools

Article submitted 2019-09-23. Resubmitted 2019-10-22. Final acceptance 2019-10-28. Final version published as submitted by the authors. 